\title{
The Contexts for Learning and Instruction Influencing Ghanaian JSS2 Students' Dismal Performance in TIMSS-2003
}

\author{
Anamuah-Mensah, J., Mereku, D. K. and Asabere-Ameyaw, A. \\ University of Education, Winneba
}

\begin{abstract}
In 2003, Ghana for the first time participated in TIMSS in order to find out how the performance of her eighth graders (JSS2) in science and mathematics compared with those of other countries. This involved a total of 5,114 JSS2 students in 150 schools sampled across the country. The Ghanaian JSS2 students' overall attainment in the TIMSS-2003 in mathematics and science was poor. This dismal performance placed Ghana at the 45th position on the overall mathematics achievement results table in the two subjects. This paper discusses some of the contexts for learning and instruction within and outside the school that had influenced such an abysmal performance. The analysis indicated that science and mathematics, which are key curriculum areas that are fundamental to the development of technologically literate societies, are subjects that are highly valued by Ghanaian students. The analysis also revealed that higher students' achievement in science and mathematics was associated with higher levels of parents' education. Also many of the students who had high expectations for university education were from parent who had university education. The analysis further revealed that homes where students had their own study table, had access to books and had the opportunity to speak English positively affected achievement in science and mathematics. Finally, it revealed that teachers emphasized methods that focus on knowledge and understanding of basic facts and principles and used instructional strategies that gave students little opportunity to design experiments (or investigations) in science and decide procedures for solving problems in mathematics.
\end{abstract}

Key words: TIMSS; science achievement; mathematics achievement; learning contexts

\section{Introduction}

Students' home backgrounds and attitudes play a key role in understanding their achievement in mathematics and science; the resources for learning and the activities they engage in the schools and their homes also influence their achievement (TIMSS, 1995, 1999). Since information on these factors provide insight into students' performance, the TIMSS-2003 study also made students and teachers to complete questionnaires designed to obtain data on the home and school background characteristics including learning resources in the home; value students place on science and mathematics; students' use of English in the home, educational aspirations, selfconfidence, attitude, and participation in the learning process; as well as teachers' content coverage. Since a detailed analyses of the home and school background characteristics can be found in (Anamuah-Mensah, Mereku and Asabere-Ameyaw, 2004), the discussion in this paper will be rather brief. 
The Contexts for Learning and Instruction Influencing Ghanaian JSS2 Students' Dismal Performance in TIMSS-2003 Anamuah-Mensah, J., Mereku, D. K. and Asabere-Ameyaw, A.

\section{Students' home backgrounds Language of the home}

TIMSS-2003 was administered in English to Ghanaian JSS2 students. The 1999 TIMSS study showed that in general, there is a strong relationship between lower achievement and not speaking the language of the test (and therefore the language of instruction) in the home. This situation is true for the science and mathematics achievement of Ghanaian students as shown in Table 1 which presents students' report of how frequently they spoke English at home in relation to their mean achievement.

Table 1

JSS2 students' mean science and mathematics scores by the extent to which English was spoken in the home

\begin{tabular}{|c|c|c|c|c|}
\hline \multirow[b]{2}{*}{$\begin{array}{l}\text { Frequency of speaking } \\
\text { English in the home }\end{array}$} & \multicolumn{2}{|c|}{ Science } & \multicolumn{2}{|c|}{ Mathematics } \\
\hline & $\%$ of students & $\begin{array}{c}\text { Mean } \\
\text { Achievement }\end{array}$ & $\begin{array}{c}\% \text { of } \\
\text { students }\end{array}$ & $\begin{array}{c}\text { Mean } \\
\text { Achievement }\end{array}$ \\
\hline Always & 23 & $260(7.0)^{*}$ & 23 & $272(5.3)$ \\
\hline Almost Always & 10 & $279(10.9)$ & 10 & $295(8.7)$ \\
\hline Sometimes & 63 & $263(5.8)$ & 63 & $265(4.6)$ \\
\hline Never & 5 & $155(11.5)$ & 5 & $189(12.2)$ \\
\hline
\end{tabular}

The table shows that majority of students $(68 \%)$ in Ghana either never spoke English or did so infrequently. It also indicates that students from homes where English Language is always or almost always spoken achieved higher mean scores than those who spoke it less frequently. There may be many factors that may influence the students' performance but an important one that needs consideration is the degree to which the students are bilingual or multilingual and can use this facility in language in the learning of science and mathematics.

\section{Educational Resources in the Home}

Studies have shown that students from homes with extensive educational resources have higher achievement than those from less endowed homes (TIMSS, 1999). These resources include books, computer and study desk or table. TIMSS-1999 showed that the number of books in the home was associated with higher achievement in science and mathematics

Table 2 JSS students' estimate of number of books in the home by mean performance in science and mathematics

\begin{tabular}{|c|c|c|c|c|}
\hline \multirow[b]{3}{*}{ Books in the home } & \multicolumn{2}{|c|}{ Science } & \multicolumn{2}{|c|}{ Mathematics } \\
\hline & & Mean & & Mean \\
\hline & $\%$ of students & Achievement & $\%$ of students & Achievement \\
\hline More than 200 & 10 & $259(11.1)$ & 10 & $275(7.2)$ \\
\hline $101-200$ & 6 & $276(13.8)$ & 6 & $300(9.6)$ \\
\hline $26-100$ & 16 & $277(8.2)$ & 16 & $294(7.8)$ \\
\hline $11-25$ & 34 & $264(6.3)$ & 34 & $285(6.0)$ \\
\hline $0-10$ & 34 & $246(6.4)$ & 34 & $264(4.7)$ \\
\hline
\end{tabular}

Students in the TIMSS-2003 study were asked to estimate the number of books available in their homes by choosing from the categories: $0-10 ; 11-25 ; 26-100 ; 101-200$; and more than 200 . The result shown in Table 2 indicates that 10 percent of the students reported more than 200 books in their homes, and 68 percent were from homes with less than 25 books while 34 percent were from 
homes with 10 books or less. Generally, students from homes with fewer books have lower achievement scores in mathematics and science.

In addition to the question on the availability of books, students were asked to indicate whether or not they have a computer and a study desk or table in their homes. Table 3 shows the percentage of Ghanaian JSS2 students who had a computer or a study desk or table, together with their mean achievement in science and mathematics. About a quarter of the students reported having computer in their homes. The difference in science achievement between students without a computer at home and those with a computer was substantial (30 scale points). Similarly, the difference in mathematics achievement between those without and those with a computer in the home was 12 scale points. The mean achievement of students without computer in the home was higher than those with a computer in their homes. Thus, having a computer at home did not seem to have positive influence on achievement.

Table 3 Percentage and achievement scores of JSS2 students with computer and study desk/table in the home

\begin{tabular}{|c|c|c|c|c|}
\hline \multirow[b]{3}{*}{ Educational aid } & \multicolumn{2}{|c|}{ Science } & \multicolumn{2}{|c|}{ Mathematics } \\
\hline & & Mean & & Mean \\
\hline & $\%$ of students & Achievement & $\%$ of students & Achievement \\
\hline Have Computer & 24 & $239(7.7)$ & 24 & $272(6.4)$ \\
\hline Do not have computer & 76 & $269(6.4)$ & 76 & $284(4.8)$ \\
\hline Have Study desk/table & 60 & $280(6.4)$ & 60 & $298(4.8)$ \\
\hline $\begin{array}{l}\text { Do not have study } \\
\text { desk/table }\end{array}$ & 40 & $236(6.7)$ & 40 & $258(5.1)$ \\
\hline
\end{tabular}

In contrast to the observation that only a few students had a computer at home, a greater percentage of students $(60 \%)$ reported having a study desk or table at home. Having a study desk or table was positively related to mean achievement in science and mathematics. The achievement difference between students with a study desk or table and those without a study desk or table was 44 scale score points for science achievement and 40 for mathematics.

Although 24 percent of the students reported having a computer at home, it did not mean that they had access to this facility. Tables 4 and 5 summarise students' responses to a question asking them to indicate where they actually use a computer - at home, at school, at both places or some other places.

Table 4 Percentage and achievement scores of JSS2 students on the use of computer

\begin{tabular}{lcccc}
\hline & $\begin{array}{l}\text { Science } \\
\text { \% of } \\
\text { Use of computer }\end{array}$ & $\begin{array}{l}\text { Mean } \\
\text { Achievement }\end{array}$ & $\begin{array}{l}\text { \% of } \\
\text { students }\end{array}$ & $\begin{array}{c}\text { Mathematics } \\
\text { Mean } \\
\text { Achievement }\end{array}$ \\
\hline Use at home and in school & 9 & $209(10.3)$ & 9 & $256(7.6)$ \\
Use computer at home only & 9 & $229(11.8)$ & 9 & $258(10.3)$ \\
Use computer at school only & 21 & $233(10.8)$ & 21 & $264(8.0)$ \\
Use computer at places & 26 & $266(2.4)$ & 26 & $285(7.2)$ \\
other than home and school & & & & \\
Do not use computer at all & 34 & $281(7.8)$ & 34 & $291(6.2)$ \\
\hline
\end{tabular}


The Contexts for Learning and Instruction Influencing Ghanaian JSS2 Students' Dismal Performance in TIMSS-2003 Anamuah-Mensah, J., Mereku, D. K. and Asabere-Ameyaw, A.

Table 5 Students' use of computers to look up information for science and mathematics

\begin{tabular}{lcccc}
\hline $\begin{array}{l}\text { Frequency of use of } \\
\text { computers }\end{array}$ & $\begin{array}{l}\text { \% of } \\
\text { students }\end{array}$ & $\begin{array}{c}\text { Science } \\
\text { Mean } \\
\text { Achievement }\end{array}$ & $\begin{array}{l}\text { \% of } \\
\text { students }\end{array}$ & $\begin{array}{c}\text { Mathematics } \\
\text { Mean } \\
\text { Achievement }\end{array}$ \\
\hline At least once a week & 46 & 268 & 20 & 445 \\
At least once a month & 7 & 282 & 13 & 481 \\
A few times a year & 3 & 282 & 16 & 492 \\
Never & 10 & 268 & 37 & 470 \\
Computers are not used at all & 34 & 291 & 14 & 420 \\
\hline
\end{tabular}

Only 9 percent reported using computer exclusively at home, 21 percent used computer at school but not at home, 26 percent used computer at places other than the school and the home. Thirtyfour percent reported that they do not use computer at all. Achievement in science and mathematics were negatively related to computer usage with mean achievement highest among students who did not use computer at all (science, 281 points; mathematics, 291 points). For students who reported using computer, the highest mean achievement was among students using computers in places other than the home or the school (science, 266 points; mathematics, 285 points), probably in internet cafes or friends' home. The next highest was achievement among students using computers at school only, followed by students using computers at home but not school. The least achievement was by students using computers at home and at school (209 points).

\section{Students' Aspirations and Attitudes}

The students' general aspirations for continuing their education beyond junior secondary school; their self confidence in learning science and mathematics; and their attitudes towards science and mathematics were also examined with respect to their parents' educational level.

\section{Educational aspirations of students relative to parents}

As parents are the first models and the most important educators for children in the home, their educational attainment may serve as the source of aspiration for them. Students were therefore asked to indicate the highest level of education attained by their parents by selecting from the following categories: finished university or equivalent higher education, finished post-secondary vocational/technical education but not university, finished upper secondary schooling, finished lower secondary schooling, and no more than primary schooling. The parent with the highest level of education was used to assign students to the categories. Table 6 shows the proportion of students in each of the educational categories together with their mean achievement in science and mathematics.

A high proportion of students (37\%) indicated that the highest level of educational attainment of their parents was junior secondary school. Ten percent of Ghanaian students reported that they had university-educated parents, 17 percent had parents who finished secondary vocational/technical education but not university, and 14 percent had no more than primary education. The results indicate that higher levels of parents' education were associated with higher students' achievement in science and mathematics. 

Science and Mathematics

\begin{tabular}{lcccc}
\hline $\begin{array}{l}\text { Highest level of education of } \\
\text { either parent }\end{array}$ & $\begin{array}{l}\text { \% of } \\
\text { students }\end{array}$ & $\begin{array}{l}\text { Science } \\
\text { Mean } \\
\text { Achievement }\end{array}$ & $\begin{array}{l}\text { \%of } \\
\text { students }\end{array}$ & $\begin{array}{c}\text { Mathematics } \\
\text { Mean } \\
\text { Achievement }\end{array}$ \\
\hline $\begin{array}{l}\text { Completed university or } \\
\text { equivalent level }\end{array}$ & 10 & $310(9.5)$ & 10 & $320(8.1)$ \\
$\begin{array}{l}\text { Completed post-secondary } \\
\text { TVET }\end{array}$ & 17 & $285(8.5)$ & 17 & $296(6.7)$ \\
Completed secondary school & 22 & $276(7.3)$ & 22 & $292(5.8)$ \\
Completed JSS & 37 & $235(6.6)$ & 37 & $261(5.7)$ \\
Not beyond primary school & 14 & $223(5.8)$ & 14 & $246(5.5)$ \\
\hline
\end{tabular}

Table 7 presents students' responses on their educational aspiration relative to their parents' educational level. About a quarter of the students (27\%) had high expectations for university education. Out of this, 6 percent aspired to have university education just as their parents. Twenty-one percent aspired to finish university education even though neither parents had university education. Majority of the students $(67 \%)$ did not expect to complete university education whereas 7 percent did not know the level of education to aspire to.

Table 7

Students' educational aspirations relative to Parents' Educational level by mean Performance in Science and Mathematics

\begin{tabular}{|c|c|c|c|c|}
\hline \multirow[b]{2}{*}{$\begin{array}{l}\text { Highest level of education aspired } \\
\text { by students }\end{array}$} & \multicolumn{2}{|c|}{ Science } & \multicolumn{2}{|c|}{ Mathematics } \\
\hline & $\begin{array}{c}\text { \% of } \\
\text { students }\end{array}$ & $\begin{array}{c}\text { Mean } \\
\text { Achievement }\end{array}$ & $\begin{array}{c}\% \text { of } \\
\text { students }\end{array}$ & $\begin{array}{c}\text { Mean } \\
\text { Achievement }\end{array}$ \\
\hline $\begin{array}{l}\text { Finish university and either parent } \\
\text { went to university or equivalent }\end{array}$ & 6 & $350(10.8)$ & 6 & $351(8.6)$ \\
\hline $\begin{array}{l}\text { Finish university but neither parent } \\
\text { went to university or equivalent }\end{array}$ & 21 & $318(7.8)$ & 21 & $318(6.8)$ \\
\hline $\begin{array}{l}\text { Not finish university regardless of } \\
\text { parents' education }\end{array}$ & 67 & $239(5.3)$ & 67 & $263(3.9)$ \\
\hline $\begin{array}{l}\text { Do not know regardless of parents' } \\
\text { education }\end{array}$ & 7 & $198(12.1)$ & 7 & $247(6.9)$ \\
\hline
\end{tabular}

The very high percentage of students who did not aspire to have university education raises a number of concerns, including the value of university education to such students and how easily accessible universities were to them. Judging from the large number of junior secondary students who drop out or fail to gain admission to senior secondary schools, and the high proportion of senior secondary students who are also unable to enter universities every year, most students, especially those in rural areas, are most likely to regard school work as the most unproductive use of their time. Students expecting to complete university education had higher mean performance in science and mathematics than those who did not expect to have university education. Out of those expecting to complete university education, the mean achievement of those students with a parent who completed university $(6 \%)$ was 32 points greater than those without a universityeducated parent $(21 \%)$.

\section{Students' self-confidence in learning science and mathematics}

TIMSS-2003 created two indices, the Index of Students' Self-Confidence in Learning Science (SCS) and Index of Students' Self-Confidence in Learning Mathematics (SCM) to investigate 
The Contexts for Learning and Instruction Influencing Ghanaian JSS2 Students' Dismal Performance in TIMSS-2003 Anamuah-Mensah, J., Mereku, D. K. and Asabere-Ameyaw, A.

how students think of their abilities in science and mathematics respectively. The SCS index was based on students' responses to four statements about their science ability:

- I usually do well in science

- Science is more difficult for me than for many of my classmates (reversed)

- Science is not one of my strengths (reversed)

I I learn things quickly in science.

Students were asked to use a 4-point scale to indicate whether they agree a lot, agree a little, disagree a little or disagree a lot. Students agreeing a little or a lot on average across the four statements were assigned to the high level of the index; while students disagreeing a little or a lot on average were assigned to the low level. All other students were assigned to the middle level.

A similar index (SCM) was constructed for students' self-confidence in learning mathematics based on students' responses to four statements about their mathematical ability:

- I usually do well in mathematics

- Mathematics is more difficult for me than for many of my classmates (reversed)

- Mathematics is not one of my strengths (reversed)

I learn things quickly in mathematics

Table 8 shows that about two-thirds of JSS students (57\%) had high self-confidence in learning science. This was higher than the average of 48 percent across all participating countries. In terms of their mathematical ability, 43 percent of the students expressed high self-confidence in the learning of mathematics, which is similar to the average of 40 percent across the 46 countries. The table shows a clear positive association between self-confidence in learning science and science achievement. This is depicted graphically in Figure 1(a) which also shows that internationally, students with high confidence in science performed better than those with medium or low confidence index. There is also a similar relationship between self-confidence in learning mathematics and achievement in mathematics, at the national and international level (Figure 1(b))

Table 8 Students' self confidence of their ability in science and mathematics

\begin{tabular}{lcccc}
\hline & \multicolumn{2}{c}{ Science } & \multicolumn{2}{c}{ Mathematics } \\
\cline { 2 - 5 } $\begin{array}{l}\text { Index of students' self-confidence in } \\
\text { learning science \& mathematics }\end{array}$ & $\begin{array}{c}\text { \% of } \\
\text { students }\end{array}$ & $\begin{array}{c}\text { Mean } \\
\text { Achievement }\end{array}$ & $\begin{array}{c}\text { \% of } \\
\text { students }\end{array}$ & $\begin{array}{c}\text { Mean } \\
\text { Achievement }\end{array}$ \\
\hline High & 57 & $294(6.1)$ & 43 & $306(5.6)$ \\
Medium & 36 & $224(6.2)$ & 44 & $265(4.8)$ \\
Low & 7 & $173(11.7)$ & 12 & $265(7.5)$ \\
\hline
\end{tabular}


Figure 1

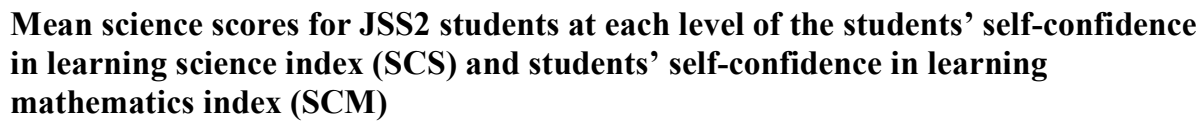
in learning science index (SCS) and students' self-confidence in learning mathematics index (SCM)

(a)

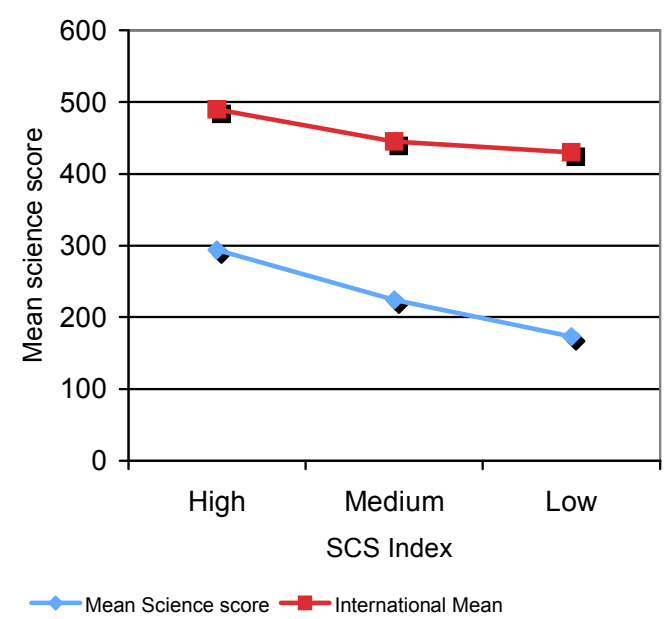

(b)

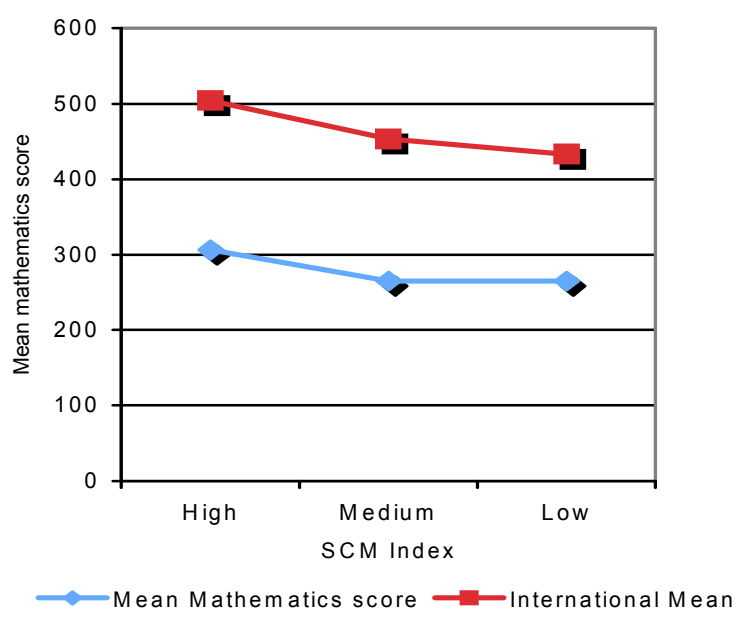

\section{Students' attitude towards science and mathematics}

The inclination of students to learn science or mathematics depends on whether they find the subject enjoyable, place value on the subject, and think it is important for success in school and for future career aspirations. An important goal of science and mathematics education in Ghana is to develop students' positive attitudes in these subjects. In order to understand the value JSS students place on science and mathematics, TIMSS constructed two indices - Index of Students Valuing Science (SVS) and the Index of Students Valuing Mathematics - based on seven separate statements for science and mathematics. The students responded to the following science statements based on a four point rating scale - strongly agree to strongly disagree:

- I would like to take more science in school

- I enjoy learning science

- I think learning science will help me in my daily life

- I need science to learn other school subjects

- I need to do well in science to get into the university of my choice

- I would like a job that involved using science

- I need to do well in science to get the job I want.

The index of students valuing mathematics was also based on similar statements, namely,

- I would like to take more mathematics in school

- I enjoy learning mathematics

- I think learning mathematics will help me in my daily life

- I need mathematics to learn other school subjects

- I need to do well in mathematics to get into the university of my choice

- I would like a job that involved using mathematics

I I need to do well in mathematics to get the job I want. 
The Contexts for Learning and Instruction Influencing Ghanaian JSS2 Students' Dismal Performance in TIMSS-2003 Anamuah-Mensah, J., Mereku, D. K. and Asabere-Ameyaw, A.

Students agreeing a little or a lot on average across the seven statements in each subject were assigned to the high level whereas those disagreeing a little or a lot on average were assigned to the low level. All other students were assigned to the middle level. Table 9 shows the proportion of students at each level of the index for science and mathematics, and their mean performance in science and mathematics.

Table 9 Index of Students' valuing science and mathematics

\begin{tabular}{|c|c|c|c|c|}
\hline \multirow{2}{*}{$\begin{array}{l}\text { Index of students' self- } \\
\text { confidence in learning science \& } \\
\text { mathematics }\end{array}$} & \multicolumn{2}{|c|}{ Science } & \multicolumn{2}{|c|}{ Mathematics } \\
\hline & $\begin{array}{c}\% \text { of } \\
\text { students }\end{array}$ & $\begin{array}{c}\text { Mean } \\
\text { Achievement }\end{array}$ & $\begin{array}{c}\% \text { of } \\
\text { students }\end{array}$ & $\begin{array}{c}\text { Mean } \\
\text { Achievement }\end{array}$ \\
\hline High & 83 & $279(5.5)$ & 82 & $293(4.8)$ \\
\hline Medium & 16 & $173(8.4)$ & 16 & $227(4.8)$ \\
\hline Low & 1 & --- & 1 & --- \\
\hline
\end{tabular}

As shown, Ghanaian students placed a high value on science and mathematics, with 83 percent and 82 percent respectively classified in the high category. This was similar to the value placed by students on science from Botswana (85\%), Egypt (83\%), Tunisia (80\%) and Morocco $(80 \%)$. Countries whose students placed a high value on mathematics as Ghanaian students did include Morocco, Botswana and Egypt.

Although Ghanaian students placed high premium on science and mathematics, their mean achievement in science and mathematics was only next to the lowest performing country in the two subjects. It could be that though students may be enthusiastic about science and mathematics, the curricula followed by the students in mathematics and science may be less demanding due to factors such as the pedagogical approach and availability of resources. The curricula may also be interesting but less challenging.

There is a positive relationship between valuing science and mean achievement in science Figure 2(a). A similar relationship seems to exist between valuing mathematics and achievement in mathematics Figure 2(b). Students with high value for science or mathematics achieved higher mean score than those with medium value for these subjects. Figure 2 indicates that although the international means were higher, the relationship between performance in the subjects and the value students place on them at the international level is not linear. 
Figure 2 Mean science and mathematics scores for JSS2 students at each level of the index of students' valuing science and mathematics compared to international mean scores

(a)

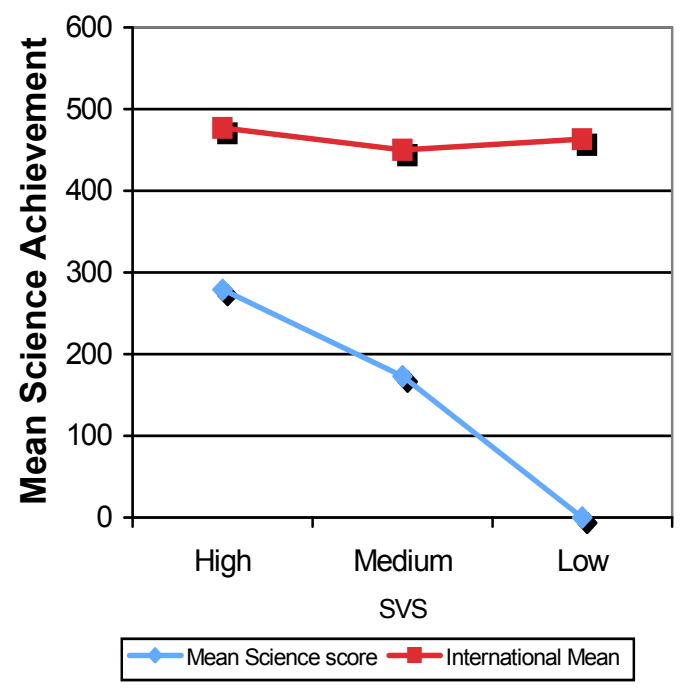

(b)

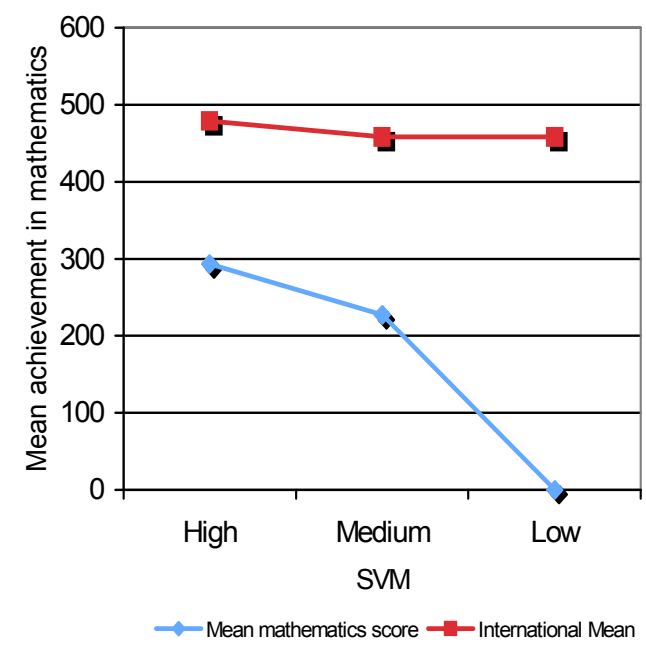

An important component of 'students valuing science index,' is 'I enjoy learning science' and that of 'students valuing mathematics index' is 'I enjoy learning mathematics'. Students indicated whether they "agree a lot," "agree a little" or "disagree" with the statements. Over 60 percent enjoyed learning science a lot while 21 percent enjoyed learning science to a lesser extent; and a slightly lower proportion (53\%) enjoyed learning mathematics a lot while 30 percent enjoyed learning mathematics to limited extent (see Figure 3).

Figure 3 Students' reaction to the statements "I enjoy learning science" and "I enjoy learning mathematics"

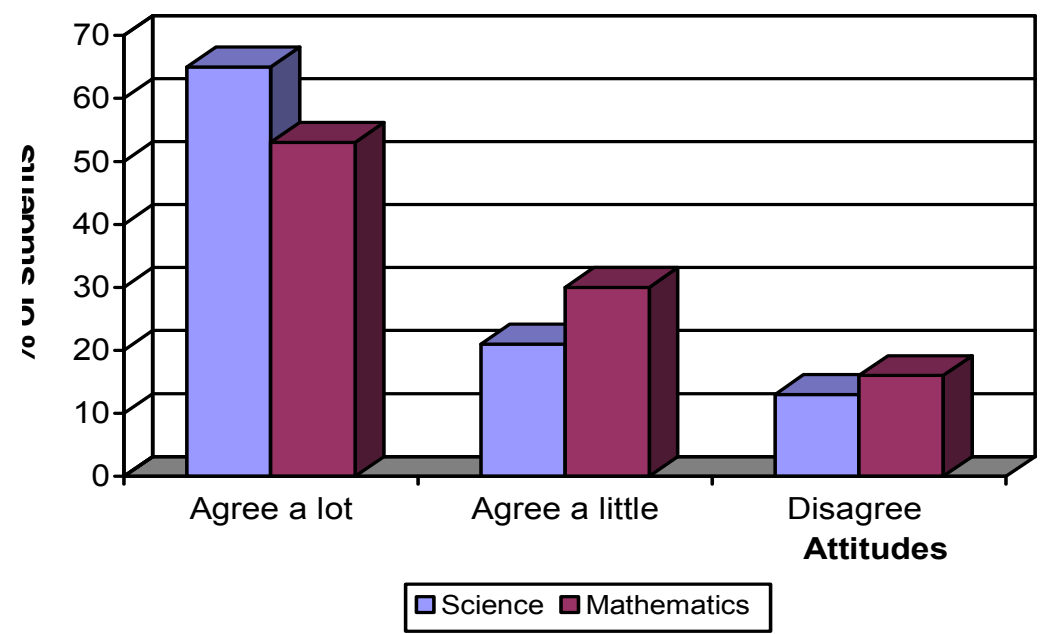

Unfortunately, this expressed enjoyment of the subjects did not reflect on their performance. Several environmental factors such as pedagogical skills, teaching and learning resources for science and mathematics teaching, and policies on education may account for this difference. But 
The Contexts for Learning and Instruction Influencing Ghanaian JSS2 Students' Dismal Performance in TIMSS-2003 Anamuah-Mensah, J., Mereku, D. K. and Asabere-Ameyaw, A.

in this paper only those related to approaches and processes emphasized in teaching the subjects will be considered.

\section{Coverage of the Curriculum}

\section{Approaches and processes emphasized}

The relative emphasis given to various aspects of science and mathematics instruction in the intended curriculum could determine what is learnt by the students. In the intended science curriculum, a lot of emphasis is placed on learners knowing basic science facts, understanding science concepts, learning about the nature of science and inquiry and writing explanations about what is observed and why what is observed happens. However, less emphasis is placed on hypotheses formulation or prediction, designing and planning experiments or investigations, conducting experiments or investigations. Other processes that receive less emphasis are: integrating science with other subjects, understanding human impacts on the environment, learning about technology and its impact on society, and incorporating the experiences of different ethnic groups. Thus, it seemed that the science curriculum focuses on knowledge and understanding of basic facts and principles but gives less attention to the development of the processes of science, that is, the actual conduct of experiments or investigations.

In the intended mathematics curriculum, a lot of emphasis is placed on mastering basic skills, understanding mathematical concepts and principles, applying mathematics in real life contexts, communicating mathematically, and integrating experiences of different cultural groups. The mathematics curriculum gives less emphasis to integrating mathematics with other subjects, and gives little attention to deriving formal proofs.

\section{TIMSS topics actually taught by teachers}

The intended curricula for science and mathematics were examined to find out the extent to which the topics covered in the TIMSS-2003 assessment were included the intended curricula. In Ghana, 95 percent of TIMSS topics were expected to be taught to every student. The proportions of TIMSS topics in the five content domains of the Ghanaian intended science curriculum are presented in Table 9(a).

Table 9 Percentage of TIMSS topics in Ghana's Intended and Taught Science Curriculum in the five Content domains

(a)

(b)

\begin{tabular}{|c|c|c|c|c|}
\hline \multirow[b]{2}{*}{ Content domain } & \multicolumn{2}{|c|}{$\begin{array}{l}\text { TIMSS Science topics in } \\
\text { Ghanaian Intended } \\
\text { Curriculum }\end{array}$} & \multicolumn{2}{|c|}{$\begin{array}{l}\text { Students indicating } \\
\text { TIMSS Science topics } \\
\text { actually taught }\end{array}$} \\
\hline & $\begin{array}{l}\text { TIMSS } \\
\text { Topics } \\
(\%)\end{array}$ & $\begin{array}{c}\text { International } \\
\text { Average } \\
(\%)\end{array}$ & $\begin{array}{l}\text { Ghana } \\
(\%)\end{array}$ & $\begin{array}{c}\text { Internationa } \\
\text { Average } \\
(\%)\end{array}$ \\
\hline All Topics & 95 & 71 & 48 & 67 \\
\hline Life Science & 100 & 73 & 55 & 70 \\
\hline Chemistry & 88 & 70 & 64 & 70 \\
\hline Physics & 90 & 75 & 44 & 66 \\
\hline Earth Science & 100 & 66 & 32 & 61 \\
\hline Environmental Science & 100 & 69 & 49 & 49 \\
\hline
\end{tabular}

It shows that a great deal of the science content in the TIMSS-2003 assessment was included in the national curriculum. The TIMSS content domain with the least coverage in the intended 
curriculum was chemistry (88\%). The coverage in each of the content domains was above the international average as shown in the table. However, it seemed that high coverage of the topics in the intended science curriculum did not lead to high student performance as depicted by the low achievement of the Ghanaian students.

In science, TIMSS-2003 covered 44 science topics made up of 12 for Life Science; 8 for Chemistry; 10 for Physics; 11 for Earth Science; and 3 for Environmental Science. The overall average classroom coverage for science was 48 percent, which was lower than the international average of 67 percent. The average percentage of students taught the topics in the TIMSS-2003 assessment in the various science domains, according to the teachers are presented in Table 9(b). In general, less than 50 percent of the students were taught all the 44 science topics in the intended science curriculum. There was therefore no agreement between inclusion of the topic in the intended curriculum and the coverage of the implemented science curriculum. This may be due to the fact that many of the topics were to be taught in last term of Year 8 (JSS2) and the three terms of Year 9 (JSS3). The topic that received greatest coverage in the classroom was chemistry $(64 \%)$ followed by life science $(55 \%)$ while earth science received the least treatment in the classroom (32\%). With the exception of environment science, the coverage of the science topics was lower than the international average.

Table 10 presents the coverage of the individual science topics. In life science, the percentage of Ghanaian students taught the individual topics ranged from 10 - 88 percent. Specific concepts taught to about a quarter or less of students included the role of variation and adaptation in survival/extinction of species $(10 \%)$, and interaction of living organisms in an ecosystem $(23 \%)$. In chemistry, the percentage of students taught ranged from 26-93 percent. Specific concepts taught to about a third of the students or less were: the need for oxygen in common oxidation reactions, $(28 \%)$, and classification of familiar chemical transformations $(26 \%)$.

\section{Table 10 Range of students taught the individual topics in science and topics with low} coverage

\begin{tabular}{|c|c|c|}
\hline $\begin{array}{l}\text { Content } \\
\text { domains }\end{array}$ & $\begin{array}{l}\text { Range of } \\
\text { students taught } \\
\text { concepts }(\%) \\
\end{array}$ & Topics taught to about one-third of students \\
\hline Life Science & $10-88$ & $\begin{array}{l}\text { Role of variation and adaptation in survival or extinction of species } \\
(10 \%) \text {; interaction of living organisms in an ecosystem }(23 \%) \text {. }\end{array}$ \\
\hline Chemistry & $26-93$ & $\begin{array}{l}\text { Use of oxygen in common oxidation reactions }(28 \%) \text {; classification of } \\
\text { familiar chemical transformations }(26 \%) \text {. }\end{array}$ \\
\hline Physics & $10-89$ & $\begin{array}{l}\text { Thermal expansion and changes in volume and/or pressure }(28 \%) \text {; basic } \\
\text { property or behaviour of light }(24 \%) \text {; properties of sound }(10 \%) \text {; electric } \\
\text { circuits and relationships between voltage and current }(15 \%) \text {; properties } \\
\text { of permanent magnet }(24 \%) \text {. }\end{array}$ \\
\hline Earth Science & $15-42$ & $\begin{array}{l}\text { Earth structure and physical features }(25 \%) \text {; water on the earth }(33 \%) \text {; } \\
\text { earth's atmosphere }(29 \%) \text {; earth's water cycle }(34 \%) \text {; weather data/maps } \\
\text { and changes in weather patterns ( } 30 \%) \text {; geological processes occurring } \\
\text { over billions of years }(32 \%) \text {; formation of fossils and fossil fuels }(15 \%) \text {. }\end{array}$ \\
\hline $\begin{array}{l}\text { Environmental } \\
\text { Science }\end{array}$ & $40-60$ & -Nil- \\
\hline
\end{tabular}

In physics, the percentage of students taught ranged from 10-89 percent. Specific concepts taught to about a third or less included: thermal expansion and changes in volume and/or pressure 
The Contexts for Learning and Instruction Influencing Ghanaian JSS2 Students' Dismal Performance in TIMSS-2003 Anamuah-Mensah, J., Mereku, D. K. and Asabere-Ameyaw, A.

(28\%), basic property/behaviour of light (24\%), properties of sound (10\%), electric circuits and relationships between voltage and current $(15 \%)$, and properties of permanent magnet $(24 \%)$. In Earth Science, the percentage of students taught ranged from $15-42$ percent. Specific concepts taught to a third or less were: earth structure and physical features $(25 \%)$, water on the earth (33\%), earth's atmosphere (29\%), earth's water cycle (34\%), weather data/maps and changes in weather patterns $(30 \%)$, geological processes occurring over billions of years $(32 \%)$ and formation of fossils and fossil fuels (15\%). Finally, in environmental Science, the percentage of students taught the three topics ranged from 40-60 percent. Thus, all the three topics were taught to more than 40 percent of the students.

In the intended mathematics curriculum, 96 percent of TIMSS topics were expected to be taught to every student. The proportions of TIMSS topics in the five domains of the Ghanaian intended mathematics curriculum are presented in Table 11. This indicates that a good deal of the mathematics content in the TIMSS-2003 assessment was included in the Ghanaian national curriculum. The TIMSS mathematics content domain with the least coverage in the intended curriculum was Data (75\%). All the other content domains had 100 percent coverage which was above the international average. However, it seemed again that high coverage of the topics in the intended mathematics curriculum did not lead to high student performance as depicted by the low mathematics achievement of the Ghanaian students.

Table 11 Percentage of TIMSS topics in Ghana's Intended and Taught Mathematics Curriculum in the five Content domains

(a)

\begin{tabular}{|c|c|c|c|c|}
\hline & & a) & & \\
\hline \multirow{3}{*}{ Content domain } & \multicolumn{2}{|c|}{$\begin{array}{l}\text { TIMSS Mathematics } \\
\text { topics in Ghanaian } \\
\text { Intended Curriculum }\end{array}$} & \multicolumn{2}{|c|}{$\begin{array}{l}\text { Students indicating } \\
\text { TIMSS Mathematics } \\
\text { topics actually taught }\end{array}$} \\
\hline & TIMSS & International & & International \\
\hline & $\begin{array}{l}\text { Topics } \\
(\%)\end{array}$ & $\begin{array}{c}\text { Average } \\
(\%)\end{array}$ & Ghana (\%) & $\begin{array}{c}\text { Average } \\
(\%)\end{array}$ \\
\hline All Topics & 96 & 70 & 60 & 72 \\
\hline Number & 100 & 96 & 83 & 95 \\
\hline Algebra & 100 & 63 & 59 & 66 \\
\hline Measurement & 100 & 78 & 53 & 78 \\
\hline Geometry & 100 & 67 & 51 & 69 \\
\hline Data & 75 & 39 & 55 & 46 \\
\hline
\end{tabular}

The TIMSS-2003 mathematics test covered 45 topics, made up of 10 for Number, 6 for Algebra, 8 for Measurement, 13 for Geometry, and 8 for Data. The overall average coverage for mathematics in the classroom was 60 percent. The average percentage of students taught the topics in the TIMSS-2003 assessment in the various science domains, according to the teachers are presented in Table 5.14. Number was the topic taught by most of the teachers $(83 \%)$ while Geometry (51\%), Measurement (53\%) and Data (55\%) were the topics least taught by the teachers. There was no agreement between inclusion of TIMSS topics in the intended curriculum and the coverage of the implemented mathematics curriculum. This may be due to the fact that many of the topics in Measurement and Geometry were designed to be taught in the third term of Year 8 (JSS2) and the whole of Year 9 (JSS3). With the exception of Data, the coverage of the mathematics topics was lower than the international average. It seemed that the countries with high achievement in mathematics had high coverage of the TIMSS mathematics topics in the classroom. 
Table 12 Range of students taught the individual topics in mathematics and topics with low coverage

\begin{tabular}{lcl}
\hline $\begin{array}{l}\text { Content } \\
\text { domains }\end{array}$ & $\begin{array}{c}\text { Range of students } \\
\text { taught concepts } \\
(\%)\end{array}$ & Topics taught to about one-third of students \\
\hline Number & $61-96$ & - -Nil-- \\
Algebra & $27-88$ & $\begin{array}{l}\text { Proportional, linear and nonlinear relationships (28\%); attributes of a } \\
\text { graph (27\%). }\end{array}$ \\
Measurement & $23-74$ & Measures of irregular or compound areas (23\%). \\
Geometry & $22-85$ & $\begin{array}{l}\text { Properties of other polygons (35\%); Pythagorean theorem to find length } \\
\text { of a side (27\%); Cartesian plane-ordered pairs, equations, intercepts, } \\
\text { intersections, and gradient (33\%); relationships between 2- and 3- } \\
\text { dimensional shapes (31\%); translation, reflection, rotation, and } \\
\text { enlargement (22\%). }\end{array}$ \\
Data & $35-76$ & $\begin{array}{l}\text { Interpreting data sets (35\%); evaluating interpretations of data with } \\
\text { respect to correctness and completeness of interpretation (31\%) }\end{array}$ \\
\hline
\end{tabular}

Table 12 presents the coverage of the individual mathematics topics in the implemented curriculum and the topics taught to the least number of students. The percentage of Ghanaian students taught the individual Number topics ranged from 61 - 96 percent. That is, all the ten topics were taught to at least 60 percent of the students. In algebra, the coverage ranged from 2788 percent. The concepts taught to about a third or less of the students were: proportional, linear and non-linear relationships (28\%), and attributes of a graph (27\%).

In measurement, the percentage of students taught ranged from 23-74 percent. Individual concept taught to about a third or less was measures of irregular or compound areas (23\%). In Geometry, the percentage coverage ranged from 22-85 percent. Individual concepts taught to about a third or less were: properties of other polygons (35\%), Pythagorean theorem to find length of a side (27\%); Cartesian plane-ordered pairs, equations, intercepts, intersections and gradient (33\%), relationships between two-dimensional and three-dimensional shapes (31\%) and translation, reflection, rotation and enlargement (22\%). In Data, the percentage coverage ranged from 35-76 percent. Specific concepts taught to only about a third or less of students were: interpreting data sets, $(35 \%)$ and evaluating interpretations of data with respect to correctness and completeness of interpretation (31\%).

The low percentage coverage of some of the individual topics in science and mathematics suggests that many science and mathematics teachers did not teach these topics or avoided them because they probably did not feel well prepared and confident enough to handle them.

\section{Students' participation in the teaching-learning process}

The science curriculum in Ghana places a lot of emphasis on scientific inquiry (CRDD, 2001a). Table 13 presents students' and teachers' reports on a range of activities related to science investigations, namely, watching demonstrations, designing or planning experiments, conducting experiments, working in small groups on experiments, writing explanations of observations, and relating what is learned in science to daily lives. About 73 percent of students indicated that they watched the teacher demonstrate an experiment/investigation, 75 percent reported that they were 
The Contexts for Learning and Instruction Influencing Ghanaian JSS2 Students' Dismal Performance in TIMSS-2003 Anamuah-Mensah, J., Mereku, D. K. and Asabere-Ameyaw, A.

made to relate what is being taught in science to their daily lives. A little over half of the students reported designing or planning an experiment/investigation (54\%), conducting an experiment/investigation (55\%), and working in small groups on experiments/investigations (54\%). More than two thirds said that they were asked to write explanations about what was observed and why it happened. The above report seemed to suggest that some reasonable emphasis was placed on the performance of enquiry activities (experiments/investigations). However, there seemed to be more emphasis on demonstrations instead of group work and students performing their own experiments/investigations.

Table 13 Reports of Ghanaian Students and Teachers on doing science investigations

\begin{tabular}{|c|c|c|c|c|c|c|}
\hline \multirow[b]{2}{*}{ Reports } & \multicolumn{5}{|c|}{ Science investigations (\% of students) } & \multirow[b]{2}{*}{$\begin{array}{l}\text { Relate What } \\
\text { is Being } \\
\text { Learnt to } \\
\text { Daily Lives }\end{array}$} \\
\hline & $\begin{array}{l}\text { Watch the } \\
\text { Teacher } \\
\text { Demonstrate }\end{array}$ & $\begin{array}{c}\text { Design or } \\
\text { Plan an } \\
\text { Experiment } \\
\text { or } \\
\text { Investigation }\end{array}$ & $\begin{array}{c}\text { Conduct an } \\
\text { Experiment } \\
\quad \text { or } \\
\text { Investigation }\end{array}$ & $\begin{array}{c}\text { Work in } \\
\text { Small Groups } \\
\text { on an } \\
\text { Experiment } \\
\text { or } \\
\text { Investigation }\end{array}$ & $\begin{array}{c}\text { Write } \\
\text { Explanations } \\
\text { on What Was } \\
\text { Observed and } \\
\text { Why it } \\
\text { Happened }\end{array}$ & \\
\hline $\begin{array}{c}\text { Students' } \\
\text { reports }\end{array}$ & 73 & 54 & 55 & 54 & 64 & 75 \\
\hline $\begin{array}{c}\text { Teachers' } \\
\text { reports }\end{array}$ & 46 & 39 & 40 & 42 & 40 & 91 \\
\hline
\end{tabular}

Teachers of 46 percent of JSS students reported asking their students to watch them demonstrate an experiment/investigation in at least half of the lessons. Teachers of about 40 percent of the students reported having their students design or plan experiments/investigation, conduct experiments/investigations (40\%), work together in small groups on experiments/investigations (42\%), and write explanations about what was observed and why it happened (40\%). Teachers of majority of the students $(91 \%)$ reported getting students to relate what they learn in science to their daily lives. The results indicate that teachers had a more moderate view of the activities except where they emphasised relating what was being learnt to daily activities. Teachers placed less emphasis on students watching them demonstrate an experiment or investigation than did the students. They also placed less emphasis on students designing or planning an investigation, conducting an investigation, working in small groups on an investigation, and writing explanations on their observations and why it happened than did the students.

Table 14 presents reports by students and their teachers on a range of mathematics content activities that students engaged in their classrooms in half of the lessons. These were: practising numerical operations without a calculator, working on fractions and decimals, interpreting data in tables, charts and graphs, and writing equations and functions to represent relationships. About two-thirds $(63 \%)$ of the students reported practising numerical operations without a calculator in at least half of their lessons. About half of the students each reported working on fractions and decimals (55\%), writing equations and functions to represent relationships (54\%), and interpreting data from tables, charts and graphs $(50 \%)$. 
Table 14 Reports of Ghanaian students and teachers on frequency of students doing particular mathematics content related activities in half of the lessons

\begin{tabular}{lcccc}
\hline & \multicolumn{3}{c}{ Mathematics content activities (\% of students) } \\
& $\begin{array}{c}\text { Practice Adding, } \\
\text { Subtracting, } \\
\text { Multiplying and } \\
\text { Dividing Without } \\
\text { Using Calculator }\end{array}$ & $\begin{array}{c}\text { Work on Fractions } \\
\text { and Decimals }\end{array}$ & $\begin{array}{c}\text { Interpret Data in } \\
\text { Tables, Charts or } \\
\text { Graphs }\end{array}$ & $\begin{array}{c}\text { Write Equations } \\
\text { and Functions to } \\
\text { Represent } \\
\text { Relationships }\end{array}$ \\
\hline $\begin{array}{l}\text { Students } \\
\text { reports }\end{array}$ & 63 & 55 & 50 & 54 \\
Teachers reports & 73 & 37 & 22 & 30 \\
\hline
\end{tabular}

The teachers' reports tallied with that of their students only on the emphasis given to number activities. Teachers reported the largest percentage of students they involved in practicing numerical operations without calculators in at least half of their lessons. In contrast to students' views, teachers reported less emphasis on working on fractions (37\%), writing equations and functions to represent relationships (30\%), and far less emphasis on data interpretation (22\%).

\section{Problem-solving related emphasis in mathematics classroom}

The national mathematics curriculum places emphasis on problem solving (CRDD, 2001b). TIMSS-2003 asked students and teachers to report on the emphasis placed on the following activities: relating what was being done in mathematics to daily lives, explaining their answers, and deciding procedures for solving complex problems. Table 15 shows that about three-quarters each of the students said they were asked to explain answers $(75 \%)$ and relate mathematics to their daily lives $(71 \%)$ in half of the lessons.

Table 15 Reports of Ghanaian students and teachers on frequency of students doing mathematics problem solving related activities in half of the lessons

\begin{tabular}{cccc}
\hline & \multicolumn{2}{c}{$\begin{array}{c}\text { Mathematics problem solving activities (\% of students) } \\
\text { Relate What is Being Learnt } \\
\text { in Mathematics to their } \\
\text { Reports }\end{array}$} & $\begin{array}{c}\text { Decide Procedures for } \\
\text { Solving Complex } \\
\text { Problems }\end{array}$ \\
\hline Students' reports & 71 & 75 & 56 \\
Teachers' reports & 63 & 75 & 36 \\
\hline
\end{tabular}

More than half $(56 \%)$ of the students reported that they were given opportunities to decide procedures for problem-solving in half of the lessons. Teachers reported the same emphasis on explanations as their students. Teachers also reported less emphasis on problem-solving procedures $(36 \%)$ and relating mathematics to their daily lives $(63 \%)$ than their students.

\section{Findings}

Students from homes where English Language is sometimes or always spoken achieved higher mean scores than those who never spoke it;

Students from homes with fewer books had lower achievement scores in mathematics and science;

Having a study desk or table was positively related to mean achievement in science and mathematics; 
The Contexts for Learning and Instruction Influencing Ghanaian JSS2 Students' Dismal Performance in TIMSS-2003 Anamuah-Mensah, J., Mereku, D. K. and Asabere-Ameyaw, A.

The results indicate that higher levels of parents' education were associated with higher students' achievement in science and mathematics.

Majority of the students did not expect to complete university education, and many of the students who had high expectations for university education were from parent who had university education;

Students placed a high value on science and mathematics;

Science and mathematics curricula focus on knowledge and understanding of basic facts and principles, but give less attention to the development of scientific and mathematical processes;

There was low percentage coverage of some of the individual topics in science and mathematics;

Students are given little opportunity to design (or plan) an experiment or investigation in science; and in mathematics they are given little opportunity to decide procedures for solving problems.

\section{Conclusion}

The analysis has shown that science and mathematics, which are key curriculum areas that are fundamental to the development of technologically literate societies, are subjects that are highly valued by Ghanaian students. This is not surprising as universities in Ghana require passes in these subjects for admission to all programmes. The analysis also revealed the importance of parents' education in learning science and mathematics. Higher students' achievement in science and mathematics was found to be associated with higher levels of parents' education. Also many of the students who had high expectations for university education were from parent who had university education. The analysis further revealed other home background characteristics that positively influenced the learning of science and mathematics. Homes where students had their own study table, had access to books and had the opportunity to speak English positively affected achievement in science and mathematics. This result suggests the need for policies that will make the Non-Formal Education sector to organize programmes that will enable parents to raise their numeracy and literacy skills. Such programmes can be designed to foster a strong link between communities and schools by promoting a strong relationship between school authorities and parents to raise the latter's awareness of home background characteristics that promote successful learning.

Teachers were found to be emphasizing methods that focus on knowledge and understanding of basic facts and principles. Some topics in science and mathematics curricula were not taught to many students. Teachers used instructional strategies that gave students little opportunity to design experiments (or investigations) in science and decide procedures for solving problems in mathematics. In order to improve performance in science and mathematics in schools in Ghana, there is the need for teachers to change their methodology and pedagogy to allow students opportunities for problem-solving, development of scientific and mathematical processes and active participation in learning in the classroom.

\section{References}

Annmuah-Mensah, et al (2002). Report of the Presidential Committee to Review Education in Ghana, Accra: Ministry of Education.

Anamuah-Mensah, J., Mereku, D. K. and Asabere-Ameyaw, A. (2004). Ghanaian Junior Secondary School Students' Achievement in Mathematics and Science: Results from Ghana's participation in the 2003 Trends in International Mathematics and Science Study, Accra: Ministry of Education Youth and Sports. 
Chamberlain, M. and Walker, M. (2001). Trends in year 9 students' mathematics and science achievement-Results from New Zealand's participation in the repeat of the Third International Mathematics and Science Study. Wellington, NZ: Ministry of Education.

Curriculum Research and Development Division -CRDD-, (2001). Junior Secondary School Mathematics Syllabus, Accra: Ministry of Education

Curriculum Research and Development Division -CRDD-, (2001). Teaching Syllabus for Science: Junior Secondary School, Accra: Ministry of Education

Gonzalez, E. J., Galia, J. and Li, I. (2004). 'Scaling methods and procedures for the TIMSS-2003 mathematics and science scales'. In Martin, M. O., Mullis, I. V. S. and Chrostowski, S. J. (eds.) TIMSS-2003 technical report. Chestnut Hill, MA: International Study Centre, Boston College.

Joncas, M. (2004). 'TIMSS-2003 Sampling weights and participation rates'. In Martin, M. O., Mullis, I. V. S. and Chrostowski, S. J. (Eds.) TIMSS-2003 technical report. Chestnut Hill, MA: International Study Centre, Boston College.

Martin, M. O., Gregory, K. A. and Stemler, S. E. (2000). The TIMSS 1999 technical report. Chestnut Hill, MA: International Study Centre, Boston College.

Martin, M. O., Mullis, I. V. S., Gonzalez, E. J., and Chrostowski, S. J. (2004) TIMSS 2003 International Science Report: Findings from IEA's Trends in International Mathematics and Science Study at the Fourth and Eighth Grades, Chestnut Hill, MA: Boston Colege

Martin, M. O., Mullis, I. V. S., Mullis, I. V. S., Gonzalez, E. J., Gregory, K. D., Smith, T. A Chrostowski, S. J., Garden, R. A., O'Connor, K. M. (2000). TIMSS 1999 International Science Report: Findings from IEA's Repeat of the Third International Mathematics and Science Study at the Eight Grade. Chestnut Hill, MA: Boston College.

Ministry of Education (2002). National Science and Technology Education Policy, Accra: Ministry of Education

Ministry of Environment Science and Technology (2000). National Science and Technology Policy Document, Accra: Ministry of Environment Science and Technology

Mullis, I. V. S., Martin, M. O., Gonzalez, E. J., and Chrostowski, S. J. (2004) TIMSS 2003 International Mathematics Report: Findings from IEA's Trends in International Mathematics and Science Study at the Fourth and Eighth Grades, Chestnut Hill, MA: Boston Colege

Mullis, I. V. S., Martin, M. O., Gonzalez, E. J., Gregory, K. D., Garden, R. A., O’Connor, K. M., Chrostowski, S. J. and Smith, T. A. (2000). TIMSS 1999 International Mathematics Report: Findings from IEA's Repeat of the Third International Mathematics and Science Study at the Eight Grade. Chestnut Hill, MA: International Study Centre, Boston College.

Mullis, I. V. S., Martin, M. O., Smith, T. A., Garden, R. A., Gregory, K. D., Gonzalez, E. J., Chrostowski, S. J. and O'Connor, K. M. (2003). TIMSS Assessment Frameworks and Specifications 2003 ( $2^{\text {nd }}$ ed.). Chestnut Hill, MA: Boston College.

Robitaille, D. F. \& Garden, R. A. (Eds.) (1996). TIMSS Monograph o.2: Research questions and study design. Vancouver, BC: Pacific Educational Press. 